\title{
Apoptosis Sel Otot Rangka dan Perubahan Berat Badan pada Tikus Diabetes yang Diberi Ekstrak Umbi Bawang Dayak (Eleutherine palmifolia L., Merr)
}

\author{
Lailia Dwi Kusuma Wardhani ${ }^{1 *}$, Olan Rahayu Puji Astuti ${ }^{1}$ \\ Fakultas Kedokteran Hewan, Universitas Wijaya Kusuma Surabaya \\ Jalan Dukuh Kupang Barat XXV No 54, Surabaya \\ *e-mail: lailia.wardhani26@gmail.com
}

\begin{abstract}
Abstrak
Tujuan dari penelitian ini adalah untuk mengetahui pengaruh antidiabetik dan antioksidan ekstrak etanol bawang dayak (Eleutherine palmifolia L., Merr) (EEBD) terhadap apoptosis sel otot rangka dan perubahan berat badan pada tikus diabetes. Induksi menggunakan aloksan dosis tunggal $120 \mathrm{mg} / \mathrm{kgBB}$ secara intraperitoneal untuk mendapatkan tikus diabetes. Penelitian ini menggunakan dua puluh empat tikus galur Wistar umur 3 bulan. Tikus dikelompokan menjadi enam kelompok: kelompok kontrol negatif (tidak diabetes dan tidak diterapi) (KO), kelompok kontrol positif (diabetes dan diberi CMC-Na) (K1), kelompok kontrol obat (diabetes dan diterapi metformin) (K2), EEBD dosis 200 (P1), 400 (P2), 800 mg/kgBB (P3). Pemberian terapi dilakukan selama 14 hari. Pengukuran glukosa darah puasa dan berat badan dilakukan pada hari ke 7 dan 14 terapi. Akhir penelitian, tikus dikorbankan dan dilakukan pengambilan $m$. gastrocnemius untuk dibuat preparat apoptosis dengan pewarnaan TUNEL serta pengamatan atrofi dengan pewarnaan Hematoxilin-Eosin. Hasil penelitian ini mengindikasikan bahwa EBDD dapat menurunkan apoptosis sel otot rangka, mempertahankan diameter serabut otot rangka (atrofi) dan perubahan berat badan pada tikus diabetes.
\end{abstract}

Kata Kunci: bawang dayak (Eleutherine palmifolia L., Merr), diabetes mellitus, apoptosis sel otot rangka, diameter serabut otot rangka (atrofi), perubahan berat badan

\section{Skeletal Muscle Cell Apoptosis and Body Weight Change in Diabetic Rats Given Bawang Dayak (Eleutherine palmifolia L., Merr) Bulbs Extract}

\begin{abstract}
This study was undertaken to investigate the antidiabetic and antioxidant of bawang dayak bulbs (Eleutherine palmifolia L., Merr) extract (BDBE) on skeletal muscle cell apoptosis and body weight change in diabetic rat. Single doses alloxan $120 \mathrm{mg} / \mathrm{kgBW}$ were administered intraperitoneally to get diabetic rat. Twenty four male Wistar rat of three months old were used in this study. Rat were devided into six groups: negative control group (were not diabetic and treated) (KO), positive control group (were diabetic and treated CMC-Na) (K1), drug control group (were diabetic and administrated metformin as a standard drug) (K2), BDBE dosed 200 (P1), 400 (P2), and $800 \mathrm{mg} / \mathrm{kgBW}$ (P3). The treatment was conducted for 14 days. Hypoglycemic effect and body weight measured of all mice was determined at day 7 and 14 of treatment. At the end of research, all of rat were sacrificed and m. gastrocnemius were collected for apoptosis analysis by TUNEL staining and atrophy analysis by Hematoxilin-Eosin staining. The result of this study showed that BDBE decreased skeletal muscle cell apoptosis
\end{abstract}


Apoptosis Sel Otot Rangka dan Perubahan Berat Badan pada Tikus Diabetes yang Diberi...

Lailia Dwi Kusuma Wardhani, Olan Rahayu Puji Astuti

and mantained the skeletal muscle fiber diameter (atrophy) and body weight change in diabetes rat.

Keyword: bawang dayak (Eleutherine palmifolia L., Merr), diabetes mellitus, skeletal muscle cell apoptosis, skeletal muscle fiber diameter (atrophy), body weight change

\section{PENDAHULUAN}

Diabetes mellitus masih menjadi beban kesehatan dunia karena terus terjadi peningkatan insidennya (Shaw et al, 2010) dan mortalitas yang diakibatkan oleh DM tipe 2 cukup besar (Zhang et al, 2010). Indonesia berada di urutan ketujuh dengan jumlah penderita sebanyak 8,5 juta jiwa (IDF, 2015). Diabetes mellitus ditandai dengan tingginya kadar gula darah diatas nilai normal (hiperglikemia). Sampai saat ini, belum ada obat yang dapat menyembuhkan diabetes mellitus secara sempurna sehingga penderita diabetes mellitus memiliki kecenderungan untuk menggunakan insulin atau obat antidiabetes oral selama hidupnya (Bilous, 2014). Namun, seringkali penggunakan obat antidiabetes oral maupun insulin memiliki beberapa efek samping. Oleh karena itu, banyak peneliti yang menggunakan bahan dari alam berupa tanaman sebagai alternatif dalam penanganan kondisi diabetes mellitus (Lolok et al, 2019). Berbagai tanaman telah terbukti memiliki kemampuan sebagai antidiabetik salah satunya Eleutherine palmifolia L.,Merr atau sering disebut dengan bawang dayak (leyama et al, 2011).

Senyawa aktif dari ekstrak bawang dayak adalah eleutherinoside $A$, eleuthoside B, dan eleutherol. Ketiga zat aktif tersebut sebagai antidiabetik dengan cara menghambat alfa-glukoside (leyama et al, 2011). Hiperglikemia dapat meningkatkan stres oksidatif (Rains and Jain, 2011). Reactive oxigen species (ROS) dapat merusak asam nukleat, protein, lipid dan karbohidrat, yang pada akhirnya mengarah pada kerusakan sel (Khorramabadi et al, 2019). Kerusakan sel dapat berupa apoptosis melalui proses fragmentasi DNA. Apoptosis memainkan peran penting pada atrofi otot rangka. Hal ini dapat disimpulkan dari beberapa penelitian bahwa adanya peningkatan pada peningkatan apoptosis otot rangka, yang dapat diukur dengan pewarnaan TUNEL (Smith et al, 2000).

Keadaan apoptosis dapat berpengaruh pada perubahan berat badan dan juga atrofi pada otot. Penurunan masa otot berhubungan dengan pembongkaran otot dan imobilisasi, penurunan secara serentak jumlah inti setiap serabut otot 
dan peningkatan fragmentasi DNA (Smith et al, 2000). Sel yang mengalami apoptosis akan terjadi kerusakan nukleus yang berpengaruh pada metabolisme yang lain. Persyarafan dari otot akan terganggu. Awal dari denervasi atrofi otot dihubungkan dengan adanya peningkatan fragmentasi DNA. Otot yang terdenervasi akan banyak berisi Bax dibanding $\mathrm{Bcl}-2$, hal ini menandakan adanya kerentanan terhadap apoptosis (Cotrand et al, 2012).

Penelitian ini bertujuan untuk membuktikan pengaruh ekstrak bawang dayak (Eleutherine palmifolia L., Merr) terhadap apoptosis sel otot rangka dan perubahan berat badan pada tikus yang diinduksi aloksan serta hubungan antara apoptosis dengan atrofi (diameter serabut) otot rangka dan perubahan berat badan.

\section{BAHAN DAN METODE}

Penelitian ini menggunakan 24 ekor tikus jantan berumur 3 bulan strain Wistar dengan berat badan 175 - 200 gram. Induksi diabetes pada tikus menggunakan aloksan monohidrat (aldrich cat no: 741310G), ekstrak etanol bawang dayak, obat generik metformin $500 \mathrm{mg}$, sterilised water for injections Otsu-WI ${ }^{\circledR}$ sebagai pelarut aloksan, TUNEL Apoptosis detection kit (enogene cat no: BA2150), dan bahan yang digunakan dalam pewarnaan HematoksilinEosin (HE).

Alat yang digunakan untuk mengukur glukosa darah adalah glukometer Easy Touch $^{\circledR}$ GCU dan glucose strip test Easy Touch $^{\circledast}$. Peralatan untuk menimbang berat badan tikus menggunakan camry digital scale satuan gram serta alat untuk pemeriksaan apoptosis dan pengukuran diameter serabut otot rangka dengan menggunakan mikroskop Nikon Eclipse / DSFI/2 / NIS BR40.

Dosis ekstrak bawang dayak yang diberikan adalah 200, 400, dan 800 $\mathrm{mg} / \mathrm{kgBB}$ diberikan peroral. Dosis metformin pada manusia adalah 500 $\mathrm{mg} /$ per tablet (Suherman, 2007), dosis ini akan dikonversikan pada tikus didapat dosis untuk tikus sebesar $45 \mathrm{mg} / \mathrm{kgBB}$.

Proses pengkondisian tikus diabates dengan induksi aloksan. Dosis aloksan yang digunakan sebanyak $120 \mathrm{mg} / \mathrm{kgBB}$ dosis tunggal diberikan secara intraperitoneal (Febrienda dkk., 2014). Pada hari ke-4 dicek kadar glukosa darah. Tikus diabates ditandai dengan adanya kadar gula darah puasa $\geq 135 \mathrm{mg} / \mathrm{dL}$ (Wulandari, 2010). 
Apoptosis Sel Otot Rangka dan Perubahan Berat Badan pada Tikus Diabetes yang Diberi... Lailia Dwi Kusuma Wardhani, Olan Rahayu Puji Astuti

Perlakuan tiap kelompok sebagai berikut :

$\begin{array}{ll}\text { Kelompok kontrol negatif (KO) } & \text { : non-diabetes dan tanpa terapi. } \\ \text { Kelompok kontrol positif DM (K1) } & \text { : diabetes dan pemberian CMC-Na } \\ \text { Kelompok kontrol positif obat (K2) } & \text { : diabetes dan pemberian Metformin } \\ \text { Kelompok perlakuan } 1 \text { (P1) } & : \text { diabetes dan terapi ekstrak bawang dayak dosis } 200 \\ & \mathrm{mg} / \mathrm{kgBB} / \mathrm{hari} .\end{array}$

Kelompok perlakuan 2 (P2)

: diabetes dan terapi ekstrak bawang dayak dosis 400 $\mathrm{mg} / \mathrm{kgBB} / \mathrm{hari}$.

Kelompok perlakuan 3 (P3)

: diabetes dan terapi ekstrak bawang dayak dosis 800 $\mathrm{mg} / \mathrm{kgBB} / \mathrm{hari}$.

Perlakuan penelitian selama 14 hari.

Pengukuran glukosa darah puasa dan berat badan tikus pada pada saat terapi dilakukan pada hari ke-7 dan ke-14. Tikus dikorbankan dan dilakukan pengambilan organ m.gastrognemius sisi kanan tikus untuk dibuat preparat. Preparat apoptosis dengan pewarnaan TUNEL, dan untuk pengukuran diameter serabut otot rangka dengan preparat pewarnaan HematoksilinEosin.

Pengamatan presentase apoptosis sel otot rangka dilakukan dengan menggunakan mikroskop perbesaran 400x. Satu miosit dianggap apoptosis jika terdapat setidaknya dua inti sel yang terwarnai oleh apoptag detection kit. Hal ini untuk mencegah terhitungnya inti sel lain seperti inti sel endotel. Presentase miosit positif apoptosis dihitung dari setidaknya pada 200 miosit (Agusti et al, 2002). Pengukuran diameter serabut otot rangka dilakukan dengan menggunakan mikroskop perbesaran 400x dan 1000. Pengukuran dilakukan pada 5 lapang pandang dengan tiap lapang pandang dilakukan 10 pengukuran. Diameter serabut otot rangka adalah jarak antara satu serabut otot yang dipisahkan oleh endomisium pada satu bundel serabut otot (Khan, 1971).

Penghitungan berat badan tikus diukur dengan menggunakan alat penimbang berat badan digital. Penimbangan awal berat badan tikus adalah sebelum tikus dinyatakan dalam kondisi hiperglikemia (Rosyidi, 2014). Hal ini bertujuan untuk mendapatkan nilai perbandingan berat badan tikus sebelum dan sesudah kondisi hiperglikemia dan juga diberikan terapi ekstrak bawang dayak. Perubahan berat badan yang diamati adalah berat badan pada hari ke-14 dikurangi berat badan awal setelah induksi aloksan 
ISSN 1978-2071 (Print); ISSN 2580-5967 (Online) Jurnal IImiah Kedokteran Wijaya Kusuma 9(2) : 131-144, September 2020

HASIL

Hasil pemeriksaan kadar gula darah puasa tikus diabetes yang digunakan pada penelitian ini memiliki kadar gula darah puasa $\geq 135 \mathrm{mg} / \mathrm{dL}$. Setelah tikus dalam kondisi hiperglikemia, maka dapat dilanjutkan dengan tahap pemberian terapi dengan ekstrak bawang dayak. Pengamatan presentase apoptosis sel otot rangka pada tabel 1 dan Gambar 1.
Presentase apoptosis sel otot rangka kelompok terapi dosis $400 \mathrm{mg} / \mathrm{kgBB}$ (P2) berbeda nyata dengan semua kelompok perlakuan dengan presentase apoptosis sel otot rangka paling rendah dibanding dengan kelompok terapi yang lain dan kelompok kontrol postif obat, namun lebih tinggi dibanding dengan kelompok kontrol negatif (KO).

Tabel 1. Rerata dan simpangan baku presentase apoptosis sel otot rangka

\begin{tabular}{cc}
\hline Perlakuan & Rerata \pm Simpangan Baku \\
\hline K0 & $4,62^{\mathrm{a}} \pm 0,853$ \\
K1 & $14,12^{\mathrm{e}} \pm 1,436$ \\
K2 & $8,37^{\mathrm{c}} \pm 0,629$ \\
P1 & $8,87^{\mathrm{cd}} \pm 1,250$ \\
P2 & $6,25^{\mathrm{b}} \pm 0,645$ \\
P3 & $10,25^{\mathrm{d}} \pm 0,645$ \\
\hline
\end{tabular}

Keterangan: superskrip ${ }^{\left({ }^{a b c}\right)}$ yang berbeda dalam kolom yang sama menunjukan perbedaan yang nyata $(p<0,05)$. K0 : kontrol normal. K1 : kontrol negatif. K2: kontrol positif. P1: EBDD 200 mg/kgBB. . P2: EBDD $400 \mathrm{mg} / \mathrm{kgBB}$. . P3: EBDD $800 \mathrm{mg} / \mathrm{kgBB}$
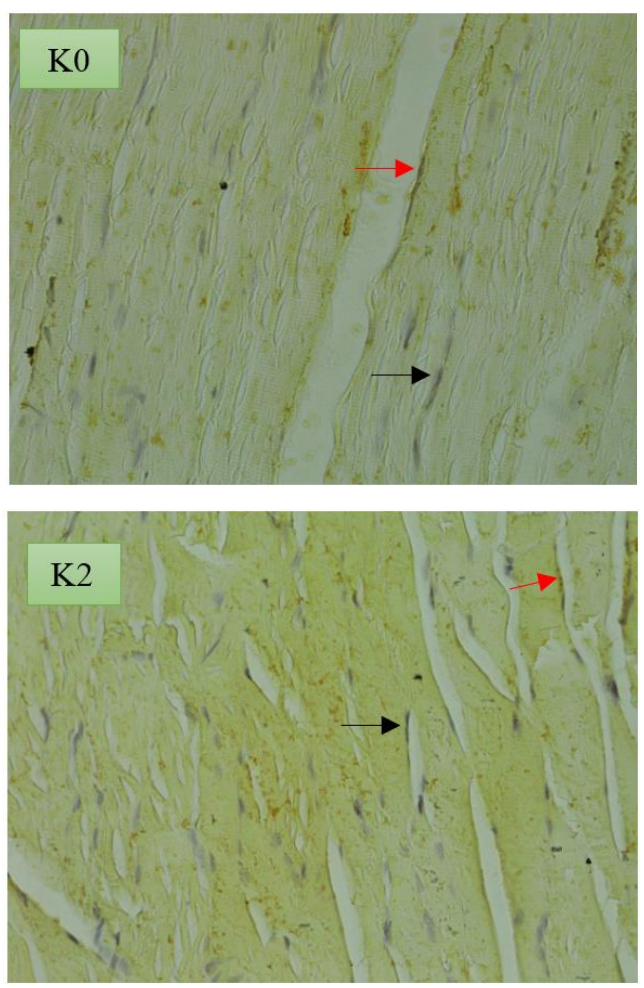
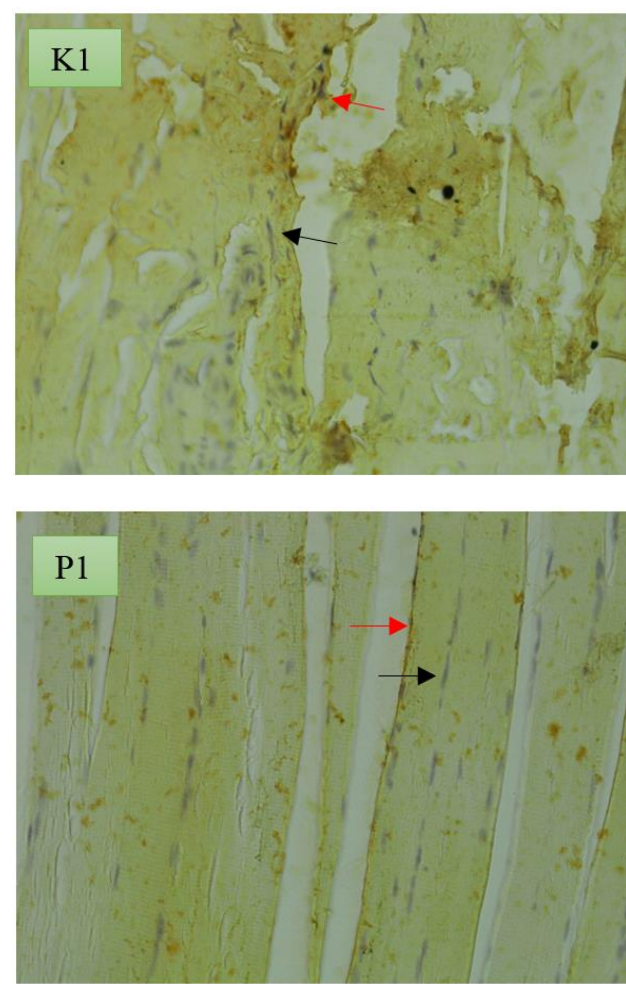

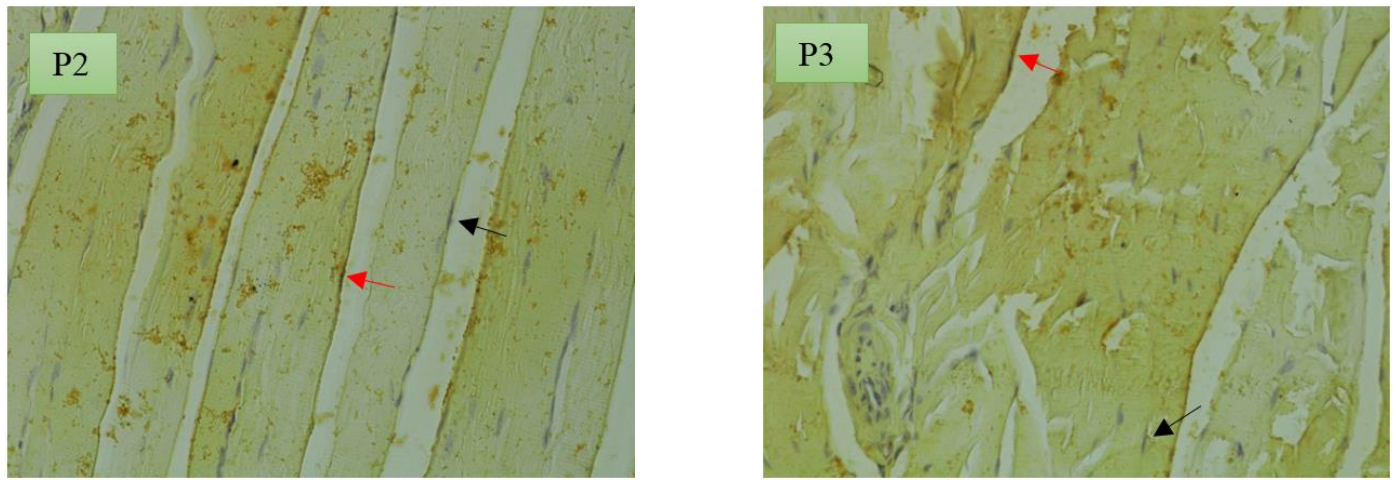

Gambar 1. Potongan membujur otot rangka pewarnaan TUNEL perbesaran 400x dengan counterstained Hematoksilin.

Keterangan: Inti sel apoptosis berwarna coklat gelap (panah merah), inti sel normal berwarna biru (panah hitam)

Pengamatan hasil diameter serabut otot rangka dapat diamati pada Tabel 2 dan Gambar 2. Kontrol positif diabetes (K1) memiliki rerata diameter serabut otot rangka yang paling rendah (pendek) dibanding dengan kelompok lain, sementara rerata diameter serabut otot rangka pada kelompok dosis terapi 400 $\mathrm{mg} / \mathrm{kgBB}$ (P2) paling tinggi (lebar).

Tabel 2. Rerata dan simpangan baku diameter serabut otot rangka

\begin{tabular}{cc}
\hline Perlakuan & Rerata \pm Simpangan Baku $(\mu \mathrm{m})$ \\
\hline K0 & $47,73^{\mathrm{d}} \pm 0,192$ \\
K1 & $44,63^{\mathrm{a}} \pm 0,351$ \\
K2 & $46,32^{\mathrm{b}} \pm 0,340$ \\
P1 & $46,39^{\mathrm{bc}} \pm 0,400$ \\
P2 & $46,88^{\mathrm{c}} \pm 0,180$ \\
P3 & $46,69^{\mathrm{bc}} \pm 0,497$ \\
\hline
\end{tabular}

Keterangan: superskrip ${ }^{(\mathrm{abc})}$ yang berbeda dalam kolom yang sama menunjukan perbedaan yang nyata $(\mathrm{p}<0,05)$. K0 : kontrol normal. K1 : kontrol negatif. K2: kontrol positif. P1: EBDD 200 mg/kgBB. . P2: EBDD $400 \mathrm{mg} / \mathrm{kgBB}$. . P3: EBDD $800 \mathrm{mg} / \mathrm{kgBB}$
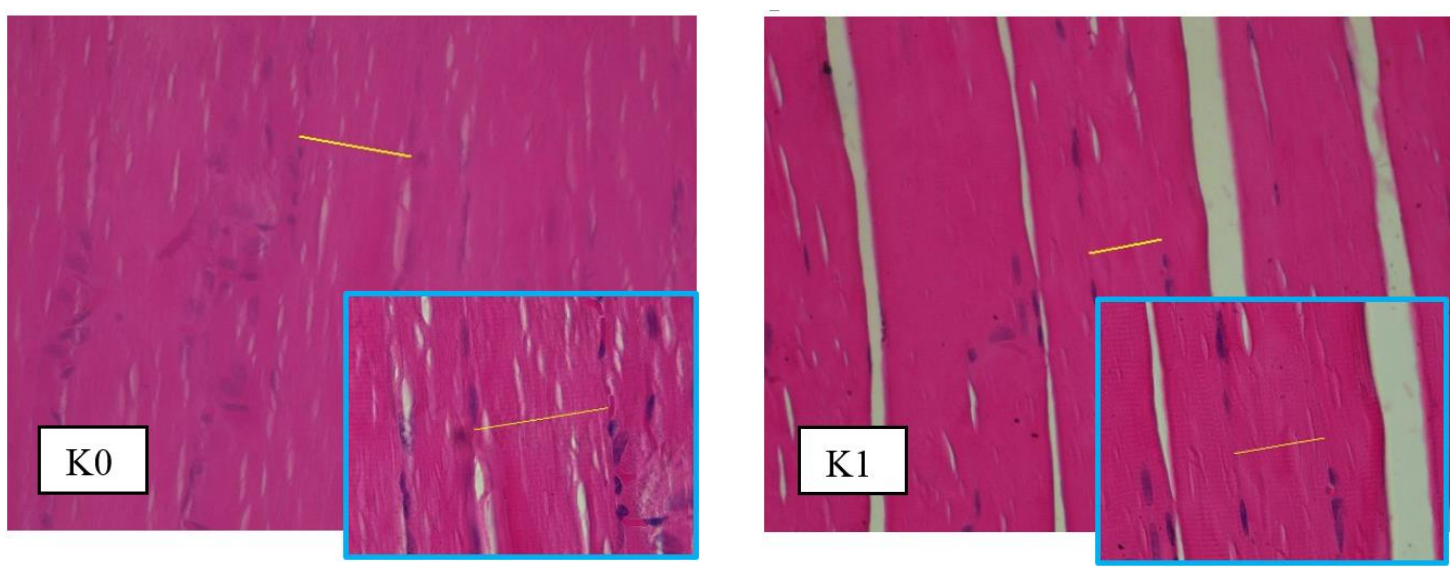

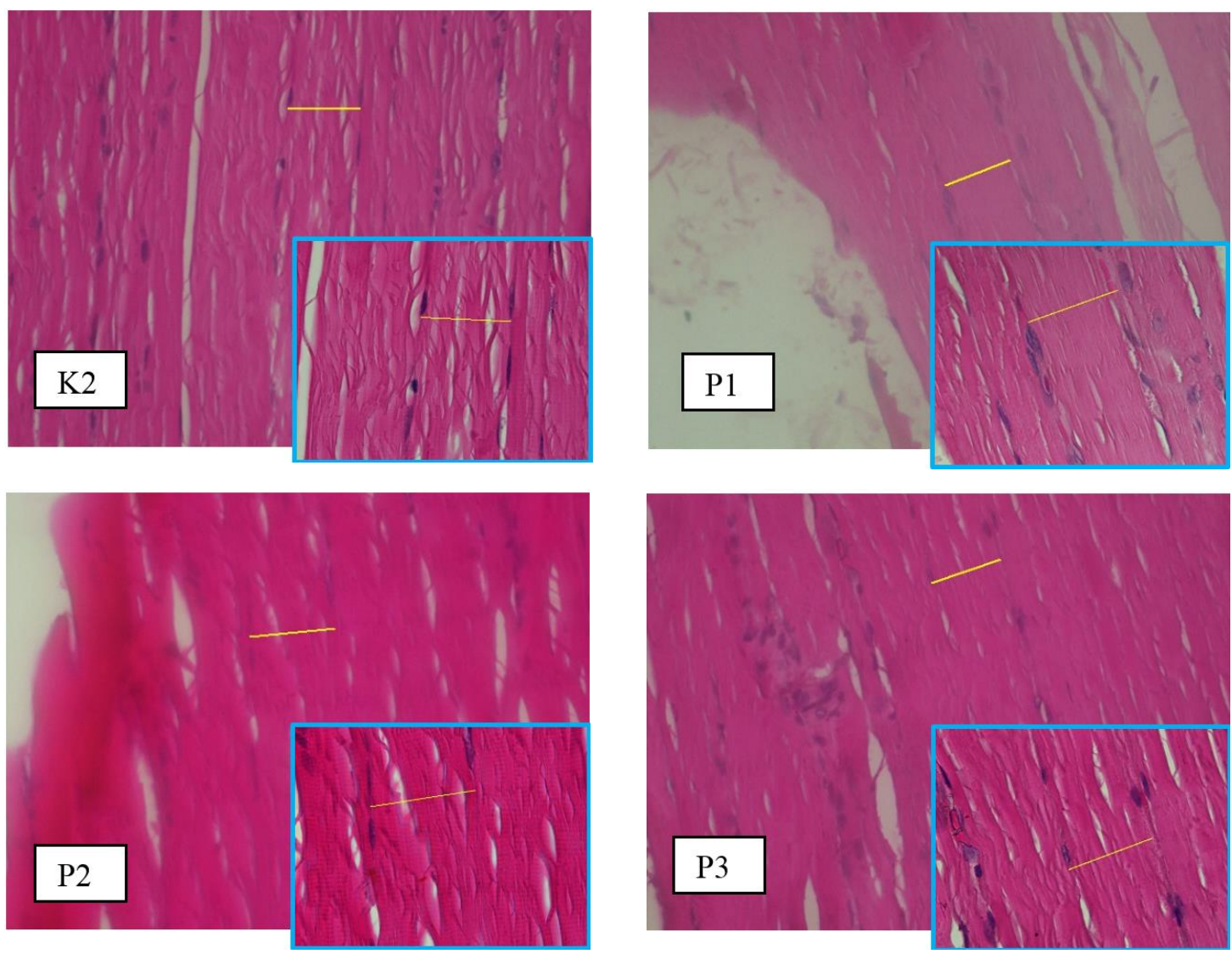

Gambar 2. Potongan membujur otot rangka dengan pewarnaan HE, kotak besar dengan perbesaran 400x, kotak kecil dengan perbesaran 1000x. (keterangan: garis kuning, menunjukan diameter serabut otot rangka)

Pengukuran perubahan berat badan dihitung dari berat badan pada hari ke-14 perlakuan dikurangi dengan berat badan awal setelah induksi aloksan. Sebelum diinduksi aloksan, berat badan tikus juga dihitung dan tidak mengalami perubahan yang signifikan (tetap). Pengamatan hasil perubahan berat badan tikus dapat diamati pada Tabel 3, menunjukkan bahwa tidak terdapat perbedaan yang nyata pada perubahan berat badan tikus semua kelompok. Kelompok K2 memiliki rerata perubahan berat badan yang paling tinggi dibanding dengan kelompok lain, sementara rerata kelompok K1 memiliki perubahan berat badan yang paling rendah dibanding dengan kelompok lain. 
Apoptosis Sel Otot Rangka dan Perubahan Berat Badan pada Tikus Diabetes yang Diberi... Lailia Dwi Kusuma Wardhani, Olan Rahayu Puji Astuti

Tabel 3. Rerata dan simpangan baku perubahan berat badan

\begin{tabular}{cc}
\hline Perlakuan & Rerata \pm Simpangan Baku (gram) \\
\hline K0 & $17,00^{\mathrm{a}} \pm 13,038$ \\
K1 & $10,00^{\mathrm{a}} \pm 2,424$ \\
K2 & $30,00^{\mathrm{a}} \pm 21,275$ \\
P1 & $15,00^{\mathrm{a}} \pm 3,829$ \\
P2 & $27,50^{\mathrm{a}} \pm 10,847$ \\
P3 & $19,50^{\mathrm{a}} \pm 11,733$ \\
\hline
\end{tabular}

Keterangan: superskrip ${ }^{(\mathrm{abc})}$ yang berbeda dalam kolom yang sama menunjukan perbedaan yang nyata $(p<0,05)$. K0 : kontrol normal. K1 : kontrol negatif. K2: kontrol positif. P1: EBDD 200 mg/kgBB. . P2: EBDD $400 \mathrm{mg} / \mathrm{kgBB}$. . P3: EBDD $800 \mathrm{mg} / \mathrm{kgBB}$

\section{PEMBAHASAN}

Aloksan bisa masuk ke sitosol sel $\beta$ pankreas melalui GLUT-2 di membran plasma sel $\beta$ pancreas yang menyebabkan reaktivitas grup Thiol sehingga terjadi penghambatan glukokinase. Hal ini menyebabkan penurunan oksidasi glukosa dan penurunan ATP, yang dapat mengaktifkan penutupan kanal $\mathrm{K}^{+}$pada membran sel sehingga menyebabkan ion $\mathrm{Ca}^{2+}$ di sitoplasma. Keadaan ini akan berakibat adanya penekanan pada sekresi insulin yang diinduksi glukosa (Rohilla and Ali, 2012).

Berkurangnya sekresi insulin menyebabkan hubungan yang seimbang antara proteoma otot rangka dengan fisiologi mitokondria otot rangka itu sendiri. Kerusakan mitokondria pada otot rangka akan mengakibatkan respon mitokondria terhadap insulin menurun dan menyebakan gangguan pengikatan substrat, yang mana akan terjadi resistensi insulin. Sekresi insulin menurun akibat induksi aloksan pada tikus diabetes berdampak pada penurunan produksi ATP di mitokondria, mengurangi coupling dan efisiensi fosforilasi, dan terjadi peningkatan oksidan pada otot rangka. Perubahan mitokondria selama gangguan pada sekresi insulin akan berkaitan dengan peningkatan degradasi protein di mitokondria dan penurunan sintesis protein, sehingga mengurangi jumlah protein yang terlibat dalam respirasi mitokondria dan $\beta$-oksidasi. Namun, regulasi protein yang terlibat pada pemanfaatan asam lemak memicu akumulasi produk oksidasi asam lemak tidak lengkap di otot skelet (Zabielski et al, 2016). Studi sebelumnya mengatakan bahwa asam lemak rantai panjang (COAs) menumpuk di otot selama kondisi defisiensi insulin (Zabielski et al, 2014), dan oksidasi asam lemak rantai panjang (FAs) dapat meningkatkan produksi ROS pada otot (Selfert et al, 2010).

Jalur apoptosis akibat ROS adalah: (1) Agen penjejas akan mencederai DNA sehingga menimbulkan akumulasi p53, (2) p53 mengaktifkan gen proapoptosis 
ISSN 1978-2071 (Print); ISSN 2580-5967 (Online) Jurnal Ilmiah Kedokteran Wijaya Kusuma 9(2) : 131-144, September 2020

sehingga akan mengaktifkan caspase, (3) Caspase akan menimbulkan perubahan pada inti dan sitoskeleton dengan mengaktifkan endonuklease dan protease yang akan menyebabkan degradasi sitoskeleton dan protein inti sehingga terjadi fragmentasi kromatin inti, kerusakan sitoskeleton akan menimbulkan pembentukan dari pembesaran sitoplasma, (4) Pembesaran sitoplasma diikuti fragmen menjadi sejumlah badan apoptotik yang disusun oleh sitoplasma, organel dengan atau tanpa fragmen inti, (5) Badan apoptotik akan difagositosis oleh sel makrofag (Cotran, 2012).

Bawang dayak dapat digunakan sebagai antidiabetik. leyama et al (2011), mengungkapkan senyawa aktif dari ekstrak bawang dayak adalah eleutherinoside $A$, eleutherinoside $B$, dan eleutherol. Ketiga senyawa turunan naphtalene tersebut berfungsi sebagai antidiabetik dengan cara menghambat aktifitas enzim alfa-glukoside yang berfungsi untuk memecah polisakarida menjadi monomer glukosa. Mekanisme penghambatan ekstrak bawang dayak terhadap enzim alfa-glukoside berupa penghambatan kompetitif dengan cara meniru posisi transisi unit furanosidik dari substrat alami enzim tersebut (Febrienda, 2014). Bawang dayak juga mengandung senyawa antioksidan meliputi flavonoid dan polifenol (Febrienda dkk., 2013). Menurut Bettuzi et al (2006), aktivitaas antioksidan komponen polifenol ditandai dengan aktivitas yang relatif tinggi sebagai donor hidrogen atau elektron, dan kemampuan dari turunan radikal polifenol untuk menstabilkan dan memindahkan elektron yang tidak berpasangan (pemutusan rantai), serta kemampuan untuk mengelat transisi logam.

Kemampuan ekstrak bawang dayak (Eleutherine palmifolia L., Merr) terhadap penurunan presentase apoptosis sel otot rangka mengalami penurunan pada dosis $800 \mathrm{mg} / \mathrm{kgBB} /$ hari (P3) dibanding dengan dosis yang lain. Dimungkinkan pada dosis $800 \mathrm{mg} / \mathrm{kgBB} /$ hari mengalami penurunan efektifitas. Penurunan efektifitas dari ekstrak bawang dayak diduga disebabkan oleh adanya peningkatan aktifitas dari enzim pemetabolisme fase II, yakni Glutation S-transferase (GST). GST berperan dalam detoksifikasi senyawa xenobiotik di dalam tubuh melalui konjugasi dengan Glutation (GSH). Aktivitas GST yang meningkat akan mempercepat proses metabolisme sehingga masa kerja dan efek obat dalam organ atau jaringan akan menurun (Griscelli et al, 2004).

Atrofi otot terjadi sebagai bentuk respons terhadap berbagai pengrusakan, 
Apoptosis Sel Otot Rangka dan Perubahan Berat Badan pada Tikus Diabetes yang Diberi... Lailia Dwi Kusuma Wardhani, Olan Rahayu Puji Astuti

termasuk pada kasus Diabetes Mellitus Tipe 2 (DMT2) (Narici, 2011). Atrofi otot merupakan hasil keseimbangan negatif antara tingkat kontraktil sintesis dan degradasi protein. Ubiquitin-proteasome, autophagy-lisosom dan caspase-3 memediasi jalur proteolitik yang bertanggung jawab untuk degradasi protein dalam otot dan dengan demikian memberikan pengaruh pada atrofi otot (O'Neill et al, 2019). Kondisi atrofi seperti pada kasus diabetes, peningkatan aktivitas berkepanjangan jalur tersebut meningkatkan laju degradasi protein kontraktil, akhirnya menyebabkan atrofi otot (Cohen et al, 2015). Sebagai tambahan, penurunan sintesis protein ini terlihat dalam DMT2, terutama melalui penurunan aktivasi dari jalur target rapamyacin pada mamalia (mTOR) (Bassil et al, 2013). Resistensi insulin akan menurunkan insulin reseptor substrat yang dapat mengganggu transport insulin ke dalam sel otot, sehingga pemasukan glukosa ke dalam otot akan bekurang, kemudian akan memicu peningkatan ekspresi Atrogin-1. Antrogin-1 menyebabkan terjadinya degradasi protein, penurunan sintesis protein otot dan menyebabkan perubahan ukuran serabut otot atau atrofi (Bassil et al, 2013).

Berbagai gen, secara kolektif disebut "atrogenes", terlibat dalam atrofi otot
(O'Neill et al, 2019). Kemungkinan yang paling menonjol dari atrogenes otot ini adalah dua E3 ligases ubiquitin, RING otot jari 1 (MuRF1, atau TRIM63) dan Atrogin-1 (juga dikenal sebagai MAFbx atau FBXO32) (Ghomes et al, 2001). Atrogenes ini merupakan komponen kunci dari sistem ubiquitin-proteasome, yang diaktifkan oleh faktor transkripsi atrofi yakni dari keluarga transkripsi Forkhead box $O$ faktor 1 dan $3 a$ (FoxO 1 dan 3a) (Lundell et al, 2019). Pada tikus, pelepasan Atrogin-1 atau MuRF1 dapat melemah pada atrofi yang dimediasi denervasi, sedangkan Atrogin-1 dan MuRF1 serta mRNA meningkat pada atrofi yang dimediasi oleh pemuatan kaki belakang (Ebert et al, 2019), pemaparan dengan deksametason pada Myotubes (Zheng et al, 2010).

Penelitian ini memberikan hasil bahwa perubahan berat badan pada semua perlakuan tidak memberikan hasil yang berbeda nyata. Hasil penelitian Febrienda (2014), pada pemberian 100 $\mathrm{mg} / \mathrm{kgBB}$ ekstrak air dan etanol umbi bawang dayak selama 28 hari mampu mempertahankan berat badan tikus yang diinduksi aloksan. Perbedaan hasil penelitian ini dengan penelitian yang dilakukan Febrienda pada tahun 2014, dimungkinkan karena perbedaan lama terapi yang digunakan. Terapi selama 14 hari dimungkinkan belum memberikan 
ISSN 1978-2071 (Print); ISSN 2580-5967 (Online) Jurnal Ilmiah Kedokteran Wijaya Kusuma 9(2) : 131-144, September 2020

hasil yang signifikan terhadap perubahan berat badan. Kamalakkannan and Prince (2006) mengatakan bahwa penurunan berat badan pada diabetes ini mirip dengan glukoneogenesis, di mana pada jalur tersebut, ukuran otot akan lebih kecil dari normal dan juga ada kehilangan protein dalam jaringan. Pada keadaan hiperglikemik kronik, berat badan pasien diabetes harus segera dipertahankan karena akan menimbulkan keadaan infeksi yang lebih parah.

Kandungan flavonoid pada ekstrak bawang dayak juga dimungkinkan memberikan pengaruh dengan mempertahankan berat badan. Flavonoid yang juga terkandung dalam teh hijau dilaporkan memiliki fungsi biologis yakni mengkonsumsi senyawa ini dalam dosis tinggi akan mengontrol berat badan, jaringan adiposa, dan mengatur metabolisme lipid (Ashida et al, 2004). Lee et al (2011) mendukung pernyataan tersebut dengan mengatakan bahwa beberapa senyawa alam seperti katekin, capsaicin, terkonjugasi asam linoleat, fucoxanthin, isoflavon dari kedelai, astaxanthin, dan cyanidin-3-glucoside adalah senyawa efektif untuk menjaga berat badan. Glabridin, turunan flavonoid dari licorice (Glycyrrhiza glabra), dikenal mampu mempertahankan berat badan dari hewan dan manusia. Flavonoid efektif dalam mengurangi lemak intra-abdominal melalui aktivasi dari Peroksisom Proliferator-Activated Receptor- $\gamma$ (PPAR- - ) (Maksoed et al, 2018; Sasakawa et al, 2017).

\section{KESIMPULAN}

Ekstrak umbi bawang dayak dapat menurunkan apoptosis sel otot rangka dan mengembalikan kondisi atrofi (diameter serabut otot rangka), serta mempertahankan berat badan pada tikus diabetes. Perlu adanya penelitian lebih lanjut terkait lama waktu terapi dan dosis terapi, agar dapat mengamati perubahan berat badan yang lebih signifikan.

\section{DAFTAR PUSTAKA}

Agusti AC, Jaume $S$, Cristina $M$, Bernat $T$, Ernest $S$ et al, 2002. Skeletal Muscle Apoptosis and Weight Loss in Chronic Obstructive Pulmonary Disease. Am. J. Respir. Crlt. Med. 166:485-489

Ashida H, Furuyashiki T, Nagayasu H, Bessho H, Sakakibara H et al, 2004. Anti-Obesity Actions Of Green Tea: Possible Involvements In Modulation of The Glucose Uptake System And Suppression Of The Adipogenesis-Related Transcription Factors. Biofactors. 22: $135-140$ 
Apoptosis Sel Otot Rangka dan Perubahan Berat Badan pada Tikus Diabetes yang Diberi... Lailia Dwi Kusuma Wardhani, Olan Rahayu Puji Astuti

Bassil MS, and Gougeon R, 2013. Muscle

Protein Anabolism In Type 2

Diabetes.

Curr.Opin.Clin.Nutr.Metab.Care.

16: $83-88$

Cohen S, Nathan JA, and Goldberg AL, 2015. Muscle Wasting In Disease: Molecular Mechanisms And Promising Therapies. Nature. Rev. Drug. Discov. 14: 58-74

Cotran RS, Kumar V, Collius T, 2012. Robbins Pathologic Basic of Disease. $9^{\text {th }}$ ed. Philadelphia: WB Saunders Company

Ebert SM, Zougbi A, Bochine S, and Adams C, 2019. Skeletal Muscle Atrophy: Discovery of mechanism and Potencial Therapies. American Physiological Society Journal .Vol $34(4)$.

Febrinda AE, 2014. Potensi Antioksidan dan

Antidiabetik Ekstrak Air dan Etanol Umbi Bawang Dayak (Eleutherine Palmifolia) secara In Vitro dan In Vivo. Tesis. Fakultas Teknlogi Pertanian, Institut Pertanian Bogor, Bogor.

leyama T, Gunawan-Puteri MDPT, and Kawabata J, 2011. a-Glucosidase Inhibitors from the Bulb of Eleutherine americana. J. Food Chemistry .128: 308-311
International Diabetes Federation. 2015. IDFDiabetes Atlas 7th Edition. Brussels:International Diabetes Federation.http://www.diabetes atlas.org/. [Sitasi: 18 November 2016]

Kamalakkannan N, and Prince PSM, 2006. Antihyperglycaemic And Antioxidant Effect of Rutin, A Polyphenolic Flavonoid, In Streptozotocin Induced Diabetic Wistar Rats. Bas.Clinic.Pharmacol.Toxicol. 98(1): 97-103

Khan HA, 1971. Comparison of Methods for Measurement of Fiber Diameter in Skeletal Muscle. Master's Thesis. Kansas State University: 57

Khorramabadi KM, Talebi AR, Sarchehmeh A, and Mirjalili A, 2019. Protective effect of vitamin $E$ on oxidative stress and sperm apoptosis in diabetic Mice. International Journal of Reproductive BioMedicine .17(2): 127-134

Lee J, Li Y, Li C, and Li D, 2011. Natural products and body weight control. American Journal of the Medical Sciences. 3(1): 13-19.

Lolok N, Mashar HM, Annah I, Saleh A, Yuliastri WO et al, 2019. Antidiabetic Effect of The 
Combination Of Garlic Peel Extract (Allium sativum) And Onion Peel (Allium cepa) In Rats WithOralGlucose Tolerance Method. Research Joournal of Pharmacy and Technology. Fakultas Farmasi STIKES Mandala Waluya, Kendari.

Lundell L, Massart, Julie, Ali A, Anna K et al, 2019. Regulation of glucose uptake and inflammation markers by FOXO1 and FOXO3 in skeletal muscle. Molecular Metabolism. 20.

Maksoed A, Afaf DA, Mustafa Y, Reem S, and Elhariif M, 2018. Biochemical and Genetical Evaluation of Ameliorative Role of Liquorice Extract on Experimentallly Induced hepatitis. International Journal of Current Research. 10(9)

Narici MV, and de Boer MD, 2011. Disuse of the musculo-skeletal system in space and on earth. European Journal of Applied Physiology. 111: 403-420.

Rains JL, and Jain SK, 2011. Oxidative Stress, Insulin Signaling, and Diabetes. Free. Radic. Biol. Med. 50(5): 567-575

Salvesen GS, Dixit VM, 1999. Caspase Activation: The Induced Proximity
Model. Proc. Natl. Acad. Sci. USA. 96: 10964-10967.

O'Neill B, Gourav B, Christie MP, Negan T, Palbo AS et al, 2019. FoxO Transcription Factors areCritical Regulators of Diabetes-related muscle Atrophy. American Diabetes Association. 68(3): 556570

Rohilla A, and Ali S, 2012. Alloxan Induced Diabetes; Mechanism and Effects. International Journal of Research in Pharmaceutical and Biomedical Sciences. Vol 3(2): 819-823.

Shaw JE, Sicree RA, and Zimmet PZ, 2010. Global Estimates of The Prevalence of Diabetes for 2010 and 2030. Diabetes Research and Clinical Practice. 87: 4-14.

Sasakawa Y, Akari K, Michiyo A, Kaori Y, Mayumi N et al, 2017. The Antiobesity and Anti-inflammatory Effects of "LICONINE", an Extraxt of Glycyrrhiza Uralensis, on Diet=induced Obese Mice and 3T3-L1 Mouse Adipocytes. Journal of Food and Nutrition Research.5(10): 781-788

Wang H, Cui Y, Zhao C, 2010. Flavonoids of the genus Iris (Iridaceae). MiniRev. Med. Chem. 10: 63

Zabielski P, Blachnio-Zabielska A, Lanza IR, et al, 2016. Altered Skeletal 
Apoptosis Sel Otot Rangka dan Perubahan Berat Badan pada Tikus Diabetes yang Diberi... Lailia Dwi Kusuma Wardhani, Olan Rahayu Puji Astuti

Muscle Mitochondrial Proteome

As the Basis of Disruption of Mitochndrial Function in Diabetic

Mice. Am. J. Physiol. Endocrinol.

Metab. 65: 561-573

Zhang $P$, Zhang $X$, Brown J, Vistisen $D$,

Sicree $\mathrm{R}$ et al, 2010. Global

Healthcare Expenditure on

Diabets for 2010 and 2030.

Diabets. Research. Clinicl.

Practise. 87(3): 291-302
Zheng B, Ohkawa SLiH, Roberts-Wilson TK, and Price SR, 2010. FOXO3a Mediates Signaling Crosstalk That Coordinates Ubiquitin and Atrogin-1/Mafbx Expression During Glucocorticoid induced Skeletal Muscle Atrophy. FASEB J. 24: $2660-2669$ 